\title{
Työssä oppiminen yksilön ja oppimisympäristöjen välisenä vuorovaikutuksena
}

\author{
KIRSI HEIKKILÄ
}

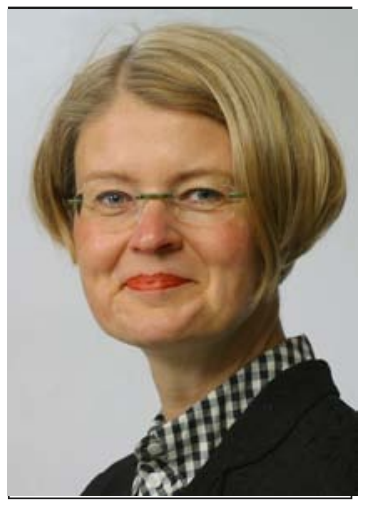

Tutkimukseni työssä oppimisesta yksilön lähtökohtien ja oppimisympäristöjen välisenä vuorovaikutuksena on yksi viidestä Tampereen yliopiston kasvatustieteiden laitokselta lyhyen ajan sisällä valmistuvasta/valmistuneesta aiheeseen liittyvästä väitöskirjasta. Teema on kansainvälisesti merkittävä ja alueen tutkimus on viime vuosikymmenellä saanut myös näkyvyyttä.
Perinteisesti työssä oppiminen on ollut jonkin työtehtävän tai ammatin oppimista työpaikalla. Lähtökohtana on ollut työtoiminta, jossa työprosessi on nähty itsessään oppimisprosessina. Tällainen oppiminen on kuitenkin usein luonteeltaan tahatonta. Intentionaalinen oppiminen on liittynyt aluksi myös työtoimintaan. Oppipojat ovat jäljitelleet tietoisesti mestareita. Vähitellen alkoi kehittyä organisoitu koulutus erillään tuotannollisesta työstä. Oppiminen oli pitkään toistavaa ja siirtävää. Sen sijaan luovaa, kriittistä, tuottavaa ja kokeilevaa oppimista tapahtui tieteen ja taiteen piirissä. Näiden yhteydessä ei puhuttu oppimistoiminnasta, vaan uuden tiedon tai esteettisten elämysten tuottamisesta. Kun oppiminen on ymmärretty konstruktiiviseksi toiminnaksi, on huomattu sen yhtäläisyydet tieteen ja taiteen luovaan aspektiin. Oppiminen nähdään tällöin toiminnaksi, jossa luodaan jotain uutta.

Kiinnostukseen työssä oppimista kohtaan on keskeisenä syynä ollut työelämässä tapahtuneet nopeat muutokset. Nämä monet muutokset ovat vaikuttaneet työntekijöiden fyysisiin, emotionaalisiin ja kognitiivisiin vaatimuksiin. Globalisaatio on keskeinen tekijä, joka on vaikuttanut tähän kehitykseen. Inhimillinen pääoma on tul- lut kansainvälisemmäksi ja koko maailma on kiinteämmin yhteydessä markkinamekanismeihin. Työvoiman joustavuuden katsotaan olevan elintärkeää markkinatalouden kehitykselle.

Jo pitkään on puhuttu tiedon merkityksen kasvusta ja sen välttämättömyydestä tuotantovoimille. Tiedosta on tullut kauppatavaraa. Tiedon merkityksen korostumisen myötä on luonnollista, että myös oppimisen merkitys on kasvanut. Kun on huomattu, että tähänastiset koulutusratkaisut eivät ole pystyneet vastaamaan kaikkiin työelämän ja teknologisen kehityksen tuomiin haasteisiin, oppimista on alettu organisoida osaksi työprosesseja. Oppiminen ja kehittyminen ovat nykyisin keskeinen osa ammattitaitoa ja osaamista. On myös väitetty, että oppiminen on uusi työn tekemisen muoto.

Yleisinä avaimina työelämän muutoksista selviämiseen on esitetty kommunikaatiotaitojen kehittämistä, perustaitojen kehittämistä, ongelmanratkaisutaitoja, tiimityöskentelyn hallitsemista sekä aloitteellisuutta ja kykyä omien tavoitteiden asettamiseen. Uudet käsitykset kompetensseista muuttavat ymmärrystä tiedosta ja kvalifikaatioista. Nykyään tärkeää ei ole vain se, mitä tiedämme tai osaamme tehdä, vaan se, kuinka 
voimme hyödyntää tietoja ja taitojamme selviytyäksemme ongelmistamme nyt ja tulevaisuudessa. Emotionaaliset, motivationaaliset ja psykodynaamiset ulottuvuudet ovat mukana siinä, kuinka toimimme. Parhaimmillaan oppimista on tuettu, kun on pyritty lisäämään työn viihtyvyyttä ja työssä jaksamista. Usein tuodaan esiin oppimaan oppimisen taitojen merkitys työelämän vaatimuksiin vastaamisessa. Juuri tällä hetkellä tarvittavat kompetenssit eivät ole riittäviä, vaan työssä oppimisessa on tarpeen suuntautua myös tulevaisuuden tarpeisiin.

Samaan aikaan kun tiedon ja oppimisen merkitys on työpaikoilla kasvanut, ovat työsuhteet muuttuneet. Ne ovat muuttuneet epäsäännöllisiksi, osa-aikaisiksi ja määräaikaisiksi. Epätyypillisissä työsuhteissa olevan työvoiman määrä vaihtelee eri maissa. Suomessa epäsäännöllisissä työsuhteissa olevien määrä on ollut koko ajan kasvussa. Näiden työntekijöiden kehittymis- ja opiskelumahdollisuudet ovat heikommat kuin kiinteässä, kokoaikaisessa työssä olevien. Työelämän muutokset ovat luoneet paineita myös työorganisaatioille. Tutkimuksella on tärkeä tehtävä pyrittäessä hahmottamaan työssä oppimisen ilmiön monet ulottuvuudet: erilaiset kilpailevat intressit sekä yksilölliset, poliittiset ja institutionaaliset vaikutukset. Markkinasuuntautuneen painotuksen ohella on myös tuotu esiin jatkuvan koulutuksen ajatus, jossa työssä oppiminen nähdään osana kansalaisuuteen kasvamista ja kokonaisvaltaista yhteisöllistä osallistumista. Yleisesti ottaen työssä oppimisen katsotaan edistävän joko työntekijöiden hyvinvointia ja työssä viihtymistä tai sen lähtökohdat ovat ennen kaikkea taloudelliset. Usein kuitenkin lähtökohtina ovat nämä kummatkin.

Työssä oppimiseen tutkimuksessa tarvitaan useita näkökulmia, koska jo työ ja organisaatiot ovat erilaisia ja luonnollisesti myös oppiminen erilaisissa konteksteissa on erilaista. Eräät tukijat ovat esittäneet, että koska erilaisia oppimisen tapoja on niin monia, ei oppimisesta ole mahdollista rakentaa yleistä teoriaa, etenkään työssä oppimiseen liittyen. Työssä oppimista on tarkasteltu monista eri näkökulmista painottaen joko yksilöllisiä tai organisaatioon liittyviä kysymyksiä. Joissakin painopisteenä on työyhteisö ja joissakin itse työtoiminta. Käsitteitä, joita lähestymistavoissa usein käytetään, ovat mm. informaali- ja satunnaisoppiminen, kokemuksellinen ja ekspansiivinen oppiminen, oppiminen osallistu- misen prosessina käytäntöyhteisössä sekä oppiva organisaatio. Näkökulmat perustuvat sekä organisaatio- että oppimistutkimuksiin. Monet niistä edustavat ajatusta, että oppimisprosessi ja työtoiminta kietoutuvat toisiinsa. Työssä oppimisen teorioissa oppimisen kontekstia pidetään keskeisenä lähtökohtana. Kontekstina voi olla itse työtoiminta, työyhteisö ja organisaatio.

Viime aikoina oppimista on käsitelty paljolti yhteisöllisenä tapahtumana, jolloin tarkastelun kohteena ovat olleet ryhmät ja yhteisöt. Oppiminen on tapa osallistua sosiaaliseen maailmaan.

Aikuiskasvatuksen alueella yhtenä suuntauksena on ollut tutkia työssä oppimista osana organisaation muutosprosessia. Kansainvälisesti työssä oppimisen tutkimus on ollut laajeneva alue, jossa on näkyvissä erilaisia lähestymistapoja, esimerkiksi yritysmaailmassa kiinnostuksen kohteena ovat jo pitkään olleet erilaiset henkilöstön kehittämisen muodot.

Väitöskirjatutkimukseni kohteena on työssä oppiminen, joka tapahtuu työpaikalla ja työn yhteydessä. Lähtökohtana on ollut tutkia kyseistä ilmiötä eri näkökulmista: miten työntekijät itse kokevat oppimisen, millaiset ovat yksilön lähtökohdat työssä oppimiselle sekä millaisia ovat teknisorganisatorinen ja sosiokulttuurinen oppimisympäristö. Tutkimuksen kohteena olevat työpaikat ovat metalliverstas, tavaratalo, uusmediayritys, saattohoitokoti ja teatteri. Tutkimuksessa lähdetään liikkeelle oppimisympäristön käsitteestä ja päädytään ajatukseen työssä oppimisen tilasta. Oppimisympäristöistä puhuttaessa esitetään tavallisesti ajatus siitä, että todellinen oppiminen tapahtuu jossakin muualla kuin luokkahuoneessa. Ainahan ihminen on selviytyäkseen hengissä oppinut. Jo alkuihmisen on täytynyt oppia monia välttämättömiä asioita selvitäkseen jokapäiväisestä elämästä. Näitä asioita opittiin luonnollisesti arjen toiminnassa; pohtimalla, kokeilemalla ja oivaltamalla.

Uudempi näkemys oppimisympäristöstä on nähdä se paikaksi, missä ihmiset voivat käyttää hyväkseen mahdollisuuksia selvittää asioita ja rakentaa toimivia ratkaisuja ongelmiinsa. Toiminta on aktiivista ja ratkaistavien ongelmien tulee olla autenttisia ja oppijalle merkityksellisiä. Oppija toimii hyödyntäen erilaisia apuvälineitä, tulkiten informaatiota ja toimien vuorovaikutuksessa toisten kanssa.

Ajatus työpaikan määrittelemisestä oppimisympäristöksi on verrattain uusi. Viime vuosina 
oppimisympäristön käsitettä on käytetty lähinnä puhuttaessa kouluympäristöstä eri muodoissaan. Sieltä se on levinnyt verkko-opiskelun tarkasteluun. Työpaikan alkuperäistarkoitus ei ole olla oppimisympäristö, joten työpaikan edellytykset muodostua oppimisympäristöksi eivät ole itsestään selvät.

Työssä oppimista ja työelämää on viime aikoina käsitelty myös tila-käsitteen kautta. Yleisesti tila-käsitettä on käytetty monin eri tavoin ja kuvaamaan hyvinkin eritasoisia ilmiöitä. Yksilötasolla sen kautta on kuvattu mielen rakennetta. Sosiaalitieteissä tila-käsitteen on todettu olevan ongelmallinen, koska se käsitetään itsestään selvänä ja toisaalta sitä ei ole käytetty analyyttisesti. Hyvin usein tila liitetään fyysiseen ympäristöön. Esimerkiksi maantieteessä valtiot esitetään karttojen muodossa. Kuitenkin näillä alueilla on myös sosiaalisia suhteita, jotka muodostavat sosiaalisia tiloja. Eräässä koulua koskevassa tutkimuksessa tila on määritelty fyysiseksi, sosiaaliseksi ja mentaaliseksi.

Oppimista varten rakennettuina tiloina on puhuttu mm. siirtymätiloista, joissa ammattilaiset voivat reflektoida muutostilanteissa omaa toimintaansa.

Jo sana työpaikka (workplace) sinänsä kiinnittää huomion tilaan. Toisaalta työssä oppimisen tutkijoiden mukaan työelämään liittyvä oppiminen ei tapahdu pelkästään työpaikoilla, vaan myös verkostoissa, kontaktissa asiakkaisiin, yksityisissä työhön liittyvissä suhteissa jne.

Japanilaiset tutkijat Nonaka ja Konno puolestaan puhuvat tiedon luomisen paikasta eli ba:sta. $B a$ on jaettu paikka esiin tuleville suhteille. Se voi olla fyysinen (esim. toimisto, liiketila), virtuaalinen (esim. sähköposti), mentaalinen (esim. jaetut kokemukset, jaetut ideat ja ideaalit) tai mikä tahansa näiden yhdistelmä. Ajatuksena on, että tiedon luominen tapahtuu yksilöiden välisessä vuorovaikutuksessa tai yksilöiden ja heidän ympäristönsä välisessä vuorovaikutuksessa eikä yksilöllisenä prosessina. Ba voidaan rakentaa intentionaalisesti tai se syntyy spontaanisti. Tutkijat ovat esittäneet tiettyjä ehtoja hyvälle ba:n toiminnalle ja näitä ovat autonomisuus, luova kaaos, ylijäämä, tarvittava moninaisuus, rakkaus, välittäminen, luottamus ja sitoutuneisuus.

Tutkimuksessani olen tarkastellut työssä oppimista kokonaisvaltaisesti. Tila-ajattelun kautta olen nostanut esiin ja yhdistänyt työssä oppimiseen liittyviä erilaisia näkökulmia. Tilan käsi- te laajentaa perspektiiviä kognitiivisista ja sosiaalisista tiloista, myös tällä alueella usein laiminlyötyihin emotionaalisiin ja fyysisiin tiloihin.

Se, mitäkaikkea tilaan sisällytetään, miten laajana ja moniulotteisena konteksti tai ympäristö nähdään, vaihtelee eri lähestymistapojen välillä. Nykyisin katsotaan, että myös ryhmät, yhteisöt ja organisaatiot, jopa kaupungit oppivat. Tilan käsite muuttaa ajattelun painopistettä, niin että kyse ei ole jostakin ulkopuolella olevasta ympäristöstä, vaan tarkastelun kohteena ovat eritasoisten ja erityyppisten prosessien leikkauspisteet. Tilan kautta on mahdollista katsoa myös yksilön tilaa, sitä mielen tilaa, jota oppimisen mahdollistuminen edellyttää. Se on mukana yhtenä tilana samalla tavalla kuin yhteisön ja organisaation oppimiselle tuottamat tilat.

Työpaikkaa tarkastellaan tällöin eri näkökulmista samanaikaisesti. Haasteeksi nousee kaleidoskooppimaisen näkymän saaminen työssä oppimisesta. Tila toimii tällöin metaforana sille paikalle, jossa eri elementit, motivaatio, identiteetti, työn luonne ja organisointi, fyysiset ja sosiaaliset aspektit kohtaavat. Joskus olosuhteiden ollessa otolliset organisaation tai yksilön toiminnan kannalta merkityksellistä oppimista tapahtuu, joskus taas ei.

Tiedon luomisen paikka ja työssä oppimisen tila voi näyttää kovin idealistiselta. Onko olemassa työpaikkoja, jotka täyttäisivät kaikki vaatimukset uuden tiedon luomiseen tarvittavasta tilasta. Eivätkö esimerkiksi työn intensiivisyys ja tuotannolliset ehdot aseta aivan toisenlaisia vaatimuksia työskentelyn suhteen?

Yhtenä esimerkkinä työelämän monista haasteista ja muutoksista voi mainita nuorten akateemisten uupumisen työelämään astumisensa kynnyksellä. Heillä on todettu olleen liian suuria odotuksia työelämän suhteen ja he ovat pyrkineet hyödyntämään liian monia mahdollisuuksia. Nuoret aikuiset hajottavat itseään moniin suuntiin. Toisaalta myös lyhyiden työsuhteiden maailmassa on jatkuvasti varmistettava eri vaihtoehtoja, joka myös kuluttaa voimavaroja. Työelämän muuttuessa yhä enemmän verkostomaiseksi ei enää löydy paikkoja identiteetin vahvistamiselle ja rakentamiselle työpaikoilta. On todettu, että yhteisöjen rajoilla toimivilta vaaditaan vahvaa identiteettiä. Missä tällaisen identiteetin kehittyminen on mahdollista? Työelämässä kaivataan erilaisia inmisiä ja toimijoita, ja kaikilla ei ole valmiina vahvaa identiteettiä. Kaikki 
eivät jaksa siirtyä jatkuvasti uudesta projektista toiseen tehden samanaikaisesti useita projekteja varmistaakseen pätevyytensä työmarkkinoilla. Elämäntilanteet vaihtelevat; välillä työntekijä tarvitsee myös rauhallisempiajaksoja työelämässä ja jopa työyhteisön tukea perhe- ja muun elämän ongelmia kohdatessaan. Oppiminen vaikeutuu ja pysähtyy, jos paineet tulevat liian suuriksi. Tarvittaisiin siis jonkinlaisia saarekkeita työpaikoille, joissa työntekijöiden olisi mahdollista tuntea olonsa turvalliseksi.

Ajatuksen turvallisesta tilasta voisi myös kasvattaa laajemmaksi koskemaan koko työelämää. Eräät tutkijat ovat ilmaisseet huolestuneisuutensa työpaikkojen kehittymisestä intensiivisinä työsysteemeinä huonoon suuntaan. Heidän esittämissään näkemyksissä kestävän kehityksen työpaikoista tavoitteena on, että työvoima uudistetaan ja sen kehittymistä edistetään. Lähtökohtana ovat seuraavat ajatukset:

- Resurssit uudistetaan systeemin sisällä ja sen toimesta. Tällöin korostetaan taitojen ja tiedon merkitystä, yhteistyötä, luottamusta, motivaatiota, työllistettävyyttä, rakentavia työelämän suhteita sekä laajempia institutionaalisia ja yhteiskunnallisia edellytyksiä, kuten koulutusmahdollisuuksia.

- Kestävän kehityksen systeemit kiinnittävät yhtä paljon huomiota työolosuhteisiin kuin organisaation suorituskykyyn ja tehokkuuteenkin. Näiden väliset riippuvuussuhteet vaativat integroitua toiminnallista lähestymistapaa.

- Kestävän kehityksen systeemien ei tulisi tuottaa staattisia olosuhteita. Koska organisaatiot ovat ympäristöinä epävakaita, kestävä kehitys merkitsee "vapauttavien rakenteiden" luomista ja sisäisen elinkelpoisuuden rakentamista jatkuviin muutoksiin ja oppimisen mahdollistamiseen.

- Kestävän kehityksen systeemit mahdollistavat mikro-ekonomisen kontekstin kasvavalle työllisyydelle. Systeemit voivat toimia yhdistävinä polkuina työttömien ihmisten tuomiselle työmarkkinoille.

Kestävän kehityksen työpaikat huolehtivat työntekijöidensä hyvinvoinnista ja jaksamisesta, jolloin myös työssä oppimisen on mahdollista olla keskeinen osa työtoimintaa. Tutkimukseni osoittaa, että erilaisissa organisaatioissa turvalliset tilat voivat muodostua eri tavoin. Työssäni kuvattu teatterin ryhmätyö antaa yhden esi- merkin, jossa edellytyksinä turvalliselle tilalle olivat, yksilön tilan suhteen, sitoutuminen, asian hallinta, itsenäisyys ja asioiden jakaminen. Sosiaalisen tilan suhteen, yhteinen tavoite, ongelmien ja tunteiden käsittely rakentavasti, positiivinen ilmapiiri, mahdollisuus kokeiluihin, toisten kunnioitus ja yhteiset työtavat (video, improvisointi jne.), sekä lisäksi fyysisen tilan mukaan ottaminen valojen, äänten, pukujen, meikkien ja lavasteiden kautta, hyödyntäen näitä tietoisesti.

Lectio. KL Kirsi Heikkilän aikuiskasvatusalan väitöstutkimus Työssä oppiminen yksilön lähtökohtien ja oppimisympäristöjen välisenä vuorovaikutuksena tarkastettiin Tampereen yliopistossa 18. helmikuuta 2006. Vastaväittäjänä oli tutkimusprofessori Päivi Tynjälä Jyväskylän yliopistosta. 